\title{
Learning Leadership Role in Funding Education in the Era of Regional Autonomy
}

\author{
Dedy Achmad Kurniady \\ Department of Educational Administration \\ Bandung, Indonesia \\ dedy_achmad@upi.edu
}

\begin{abstract}
In the era of regional autonomy, financing of education is not only the responsibility of the central government, but it is a shared responsibility between government, local government, and society. Particularly, schools' operational funding is highly demanded. Educational institutions should be more independent, creative and innovative in exploring and allocate various resources and sources of funding, specifically in education funding. Unfortunately, by implementing regional and school autonomy, the school has not received any fundamental change in its orientation of education finance. Moreover, financing at state schools still rely on government's funding while private schools tend to rely on the parental funding. To be more precise, a cost is one of the three most important things in management along with facility and time. Educational leaders in general and principals in particular have to be student-oriented, in other words, they have to focus more on students' needs because the primary mission of the school is to focus on teaching and learning. Not to mention that school effectiveness also often measured according to the students' achievement. In order to realize the aforementioned condition, it takes no small amount of funding since the role of leadership has to be applied in order to manage and arrange the education's financing. Instructional leadership is not only required to be able to pay attention to the result of students' learning process but should also be able to create a strategy in order to fulfill the necessary amount of funding in learning process.
\end{abstract}

Keywords: autonomy, financing of education, instructional leadership

\section{INTRODUCTION}

Regional autonomy is the aftereffect of reformation era, which is the change of administrational focus in government from centralistic administration to be a decentralist administration. By implementing this new system, government can now give authority for local administration to act and to make decision by itself without waiting the orders given from central administration; in other words, local administration has its own authority and can act based on its own judgment.

The rapid development of science and technology, as well as the high competition between labor marketers pressed several schools to provide the highly qualified and competitive graduates. In order to do that, there has to be some amount of funding that has to be provided. Before receiving this amount of funding, it is required for educational institution to be independent, creative, and innovative in allocating and exploring its resource and funds to maintain the educational process.

However, with the implementation of the regional and school autonomy, there is no fundamental change in the orientation of educational funding. The state schools funding still rely on government's funding while private schools rely on parental funding, which students' parents provide.

Moreover, the schools still could not optimize the school operational assistance (BOS) provided by the government, which supposed to help schools operation in educating their students. Instead, schools generally rely on government's funding without using the school operational assistance (BOS) that is particularly intended for helping schools' funding. To be more precise, funding is one of the three most important things in management, aside from facility and time. The funding management is highly required to optimize the government and society's funds specifically to help the schools operation in educating their students so that the effort of government and society will not be wasted; efficiency and effectiveness will be guaranteed.

This phenomenon needs to be investigated thoroughly since there are issues, which surround the phenomenon. The first issue is that a school has to be economically affordable, and then a school has to run several educational programs that are convenient for its students, for example, a school implants practice more than the theory. With this in mind, schools need more funds in order to work on the aforementioned operation since funds is the fundamental needs for schools to improve their ability in educating students. Without that, schools cannot operate effectively and cannot provide a high quality graduates.

The first action that has to be taken is to choose a leader that will lead all teachers to create programs required in teaching process to improve the teaching skills, and this improvement will then lead to the improvement of students' quality. The headmaster of a school is the one who has the responsibility to emphasize the learning-focused schools which covers curriculum, learning process, and assessment of students' performance which then will lead to a good strategy in exploring and collecting funds to fulfill educational needs in regional autonomy era. 
The study focused on this question: 'How is the funding system that is done by the leader in learning process will affect the result of students' performance in this regional autonomy era?'

The purpose of this study was to obtain general picture of funding system that could be done by a leader of learning process in assisting the students to improve their results in learning process in the era of regional autonomy. Furthermore, the aim of this study was to investigate about:

1. Funding system that can be implemented by a leader in learning process in each stage of elementary and junior education

2. The learning process that can be implemented in each stage of education

3. The distribution and allocation of funds intended to assist students' needs

\section{RESEARCH METHODOLOGY}

This study employed analytic-descriptive method combined with the qualitative approach to obtain the specific amount of funding. Accordingly, this method also was employed to obtain the general funding system that could be done by leader of learning process to assist the students' achievement in learning process intended for them in regional autonomy era. Correspondingly, the technique that was used to obtain the required data was: 1) observation; 2) in-depth interview; 3) document investigation.

The data in this study were divided into two categories, primary data and secondary data. Determination of sample in this research was purposeful sampling by reasons: first, the subject has been quite a blend in the school activities environment; second, the subject is still engaged fully and actively in the targeted research; third, the subject has ample times and opportunities to be interviewed. The researcher determined the key informant among all informants. The key informant in this research is the founder and leader of School Master.

The data collection technique, which conducted by researcher in the background or any natural setting as follows:

\section{A. Observation}

Observation was done by engaging with people in a situation that was being studied. In the process, the observation was made in two stages, initial observation and continuation observation. It was observed physical objects (geographic and demographic), the personnel involved in the management of resources, the actions and attitude of the personnel in carrying out the tasks related to the management of resources, the events that occurred, and time of implementation. The next stage was focused and selective in seeking social situation in education of street children in more detailed and depth according to the selected domain. The observations are documented in field notes. The note was used to define the next research activity plan.

\section{B. Interview}

The form of interviews conducted was structured interview and unstructured interview. The interview process began with the creation of rapport that was to build a supportive atmosphere, mutual trust and openness based on the principles of honesty, partnership and alignment.

Determination of informants used snowball sampling, so the founder of School Master designated as the key informant in the preliminary interview. Thus informants consisted of key informant which was the founder and leader of the school; escort informants were the chairman of the board, head of education division, head of fostering division, head of partnership division, head of research and development division; and triangulation informants were coordinator package $\mathrm{A}$, package $\mathrm{B}$ coordinator, the coordinator of the package C, life skills program coordinator, coordinator public reading; tutors and students.

\section{Document Investigation}

The documentation helped the researcher to deepen information obtained from observations and interviews. The documents were in the form of written and audiovisual or photo-voice which relate to this research.

Data analysis was performed when researcher was in the field. Data analysis is a process of structuring in systematic way to record interviews, observation and documentation. In this research, the data analysis used words, which were organized into expanded texts.

\section{DISCUSSION}

Regional autonomy is a right, authority, and obligations of regions to organize and manage their own affairs and interests of local communities, in accordance to legislation (Article 1 paragraph 5, UU 32/2004). The difference between decentralization and autonomy can be found in their method; decentralization focused on the process while autonomy focused on product or result. [1]

Independency in regional autonomy, according to some experts, has five primary components which are: (1) independency, the emergence of action within self without anything or anyone forcing; (2) progressive and strongwilled, as these aspects can be seen in chasing after achievements, full of spirit, planning and chasing after the goal and hope; (3) initiative, the ability to think and act based on self, such as assessing situation and make selfjudgment, creative, and full of initiative; (4) self-control, the ability to control self and influence others and surroundings; and (5) self-steadiness, the ability to be a steady and collected person. Hence, the independent region means that the region has its own autonomy, which is the ability to take care of its own business, affairs, and matters, to control and care for its own operational education in each region. 
The decentralization and educational autonomy were expected to improve services, qualities, and educational righteousness. However, these actions often resulted in regional discrepancy which was caused by: (1) structural poverty; the regulation, policy, planning, and budgeting that obstructed the advancement of education; (2) cultural poverty, which was caused by unproductive action and habit; and (3) natural poverty; the lack of resources and unfavorable geographical location (secluded, isolated, sprawled).

To be more precise, the pattern of educational funding underwent enough fundamental changes by the configuration of such institution. It was then mentioned in Constitution, exactly in Article 48 number 20, 2003; (1) the educational funding management is based on the principality of justice, efficiency, transparency, and public accountability; (2) the provision in managing educational funding mentioned in clause (1) will be regulated under the state's administration. Thus, every region has its own responsibility, which is a big one, to fund educational operation by spending its own Regional Government Budget (APBD). The assistance of central administration is also possible to be bestowed upon, but under circumstances according to the system of Regional Government Budget or through the notes of Regional Government Budget in the nearest sub-district or city. [2]

The monetary issues and funding are, without a doubt, the most determining and potential component and they cannot be separated in the study of educational management, particularly in operating and executing education. Furthermore, these two aspects are also the most determining component in conducting smooth and fluent learning process, along with other components. For this reason, funding is the main issue in conducting each of school's activity, consciously or unconsciously. Henceforth, this component has to be planned and controlled carefully to improve the educational operation and optimize the activity, resulting in the achievement of education's goal. This is extremely important, especially in school-based management, that is independently act and operate its own educational process by searching and utilizing some funding resources in accordance to its own needs; the general issue of education field is the lack of the funds.

Generally, the source of monetary and funds in a certain school can be grouped into three sources, (1) government, central government, regional government, or both, which is general or specific and intended for educational affairs; (2) parents or students; (3) society, be it bounded or unbounded. In accordance to the reception of money from parents and society, Constitution had stated its own policy, exactly in National Education System 1989. It was said that due to the deficiency of government in fulfilling educational funding, the responsibility of fulfilling the educational funding should be carried as a shared responsibility between government, society, and parents. This responsibility, however, encompasses the routine and construction expenses.

The education funding is a total cost of expenses spent by students individually, their families, each of resident, community groups, as well as the expenses spent by government (Dadang, Riduwan, and Enas, 2012:22). [3] Nevertheless, in Fakri Gaffar's teaching materials, it stated that educational funding is a managerial instrument to support educational management efficiently, effectively, and productively. Hence, educational funding will be more effective if it is managed professionally. [4]

In relation to the passage above, the educational funding became a shared responsibility between every aspect, such as family, society, and government. Thus, it is required to choose a leader who has an orientation and enthusiasm in improving learning quality and students' achievement to propel the entire aspects involved.

Further, there are several definitions concerning leadership although it depends on how it is being viewed and defined by an individual, and the meaning depends on the most popular issue now. Still, it can be concluded that leadership is a strength or ability possessed by someone to propel every resource, influence and guide others to achieve a certain goal.

In relation to leadership, communication in a certain organization is a need and it has to be done by a leader towards the members of community. Through communication, a leader can convey or socialize the vision, mission, as well as the goal towards the members since this is the basic form of leadership in an organization. Fakry Gaffar (1982:5) stated that communication is, without a doubt, a force that will maintain the existence of an organization, and an organization will not maintain its composure if communication is not present. In brief, the success of a leader in performing the role of leadership is determined by the communication or interaction done by him or her towards the members of organization. [5]

The leadership role in education according to Daresh and Playco (1995) is an effort to lead teachers in learning process to improve their teaching skills, which will then, resulted in the improvement of students' achievements. Then again, this definition was not comprehensive since it only focused on teachers. Other experts defined leadership as an effective learning as follows:

a. A headmaster of the school socializes and implants the meaning of his or her vision of school well. He or she also encourages others to share and discuss their opinion in constructing the vision and mission of the school, as well as maintaining the approved vision and mission of the school by people involved in discussion towards its implementation in school. 
b. A headmaster of the school involving stakeholders in managing the school (participative management). Headmaster involving stakeholders in drawing decision and school's operation in accordance to the ability and the limit of valid jurisdictions.

c. A headmaster encourages and supports learning process, for example, the headmaster states that the process of learning which focuses on students' needs should be the primary objective of the school.

d. A headmaster observes the learning process to realize and understand more about what is happening at school.

e. A headmaster has a role to be a facilitator so that he or she knows the difficulties and problems in learning process, as well as supporting and helping teachers in overcoming the difficulties.[6]

The leadership role in education or instructional leadership is a leadership which focuses on the study of its components which encompasses curriculum, learning process, assessment, teachers' assessment and improvement, primary service in learning, and the establishment of study's community in school.

The characteristics of leadership role in learning process are mainly focused on facilitating the establishment of learning's goal and its standard, socialize them, facilitating the establishment of teachers' community, aiming for high expectation, evaluating teachers' performance and the continuity of their improvement, constructing the school's culture for learning process, constructing learning person and learning school, providing time for learning, teachers, and students, giving primary service for teachers, students, and parents, coordinating them, and evaluating the result of learning process towards the successfulness of leadership role in learning process. In order to realize these, there has to be significant amount of funds and this is the main task of a leader in leading the learning process. A leader has to control, survey, and manage the educational funding. The leadership role in learning process also should not be seen as a factor that will improve the result of students' progress but it also has to create a strategy for fulfilling the amount of funds required by the school.

Eventually, the establishment of the basics and the principal of the educational funding in each region are necessary as the guide for everyone involved in it in this regional autonomy era. The principles that could be applied in relation to the regional autonomy system are:

1. Equality and equity to obtain a chance for education should not only be obtained by autonomous region in each province but it should also be obtained by autonomous region in the entire Indonesian Republic.

2. Equalizing power on the level of autonomous region of sub-district and city, on provincial level for all of autonomous region in it, and on the central level for all autonomous regions in each province in the entire Indonesian Republic.
3. The equilibrium of monetary issue on the central and provincial level should be functioned as a tool to unify the entire state and as an infrastructure to execute 'equalizing power' in the entire region of Indonesian Republic, mainly in its educational funding system.

4. On the provincial level, educational funding should be based on partnership principle between the fund source meant for province and the fund source meant for subdistrict and city.

5. The ability of region and people in funding should be used as a catalyst to determine the pattern of funds distribution for funding the educational operation in a certain area.

The aforementioned principles contain the components of foundation program and equalization program to be used as a catalyst in distributing fund resource to fund every aspect and form of education in accordance to the educational needs or citizens' educational needs.

In response to the statement above, M. Fakry (2000:32) said that there are two models in funding education by using the regional autonomy method: (1) Flat Grants; and (2) Equalization Grants, which are in the form of:

a. The allocation for regions must be equal without calculating the possibility of a variation in a stage and type of education in every region.

b. The allocation of each region is not equal since the allocation focused on the variety needs of education according to the stage and the type of education. The variation can be caused by the variation of the regional ability and citizens' funding, and by the variation of stage and type of education or educational needs of students.

c. The unit cost of first grader in elementary school is not similar to the unit cost of fourth and sixth grader, for instance. In addition, the unit cost of senior high school is not similar to the unit cost of junior high school. The weighting can be applied in order to show the variation. By applying the weighting, the unit cost of students could be known and determined to be used as a guide in allocating funds in accordance to the amount of schools' enrollment for each sub-district or city.

According to Flat Grants method, the ability of the funding on regional and local efforts is not the main focus of variation. Instead, the main concern in determining variation is the amount of students' enrollment and the weighting, which is combined by the calculation of unit cost per students or year. [4]

In contrast, according to Equalization Grants, local efforts are the main concern of funding. It means that the lower the ability in a region to fund, the higher the fund will be allocated to that region instead of other regions with the higher capability in funding. For this reason, the contribution of region should be established more to balance the amount of allocated funds for a region with equalizing 
power, for instance, the provincial region. Hence, this Equalization power is capable of supporting the poor region to maintain its composure, especially in the matter of justice and education; there is equalization established by other regions towards the poor region.

\section{RECOMMENDATION OF SUGGESTED IMPLEMENTATION OF FINANCING PATTERNS}

The recommended implementation of leadership role in funding education in accommodating the needs of students can be applied by identifying the cost driver, which is the main factor that influences the change of total costs. The cost driver connects several aspects that cause the emergence of costs, and these costs are in accordance to the eight components of National Standard Education against the object of the cost, such as product or service, where the cost is being imposed to reach the expected result of learning process in accordance to the students' needs.
Several activities and the use of resources in the process of education need to be included into the teaching and learning program, which is known as cost pool according to the cost theory (Blocher, 2005:102). [7]

Accordingly, the recommended calculation for accumulating the cost that can be implemented in every level of education is the cost calculation based on activity since the product or service is the output of activity and activity itself uses resources, which will then spend some costs. Because of this, the funds can be used effectively and efficiently to create a learning process that is suited for the needs of the students.

To illustrate the recommended method in managing the funds, here is the illustration, which describes the relationship between cost, cost pools, cost objects, and cost driver in elementary school:

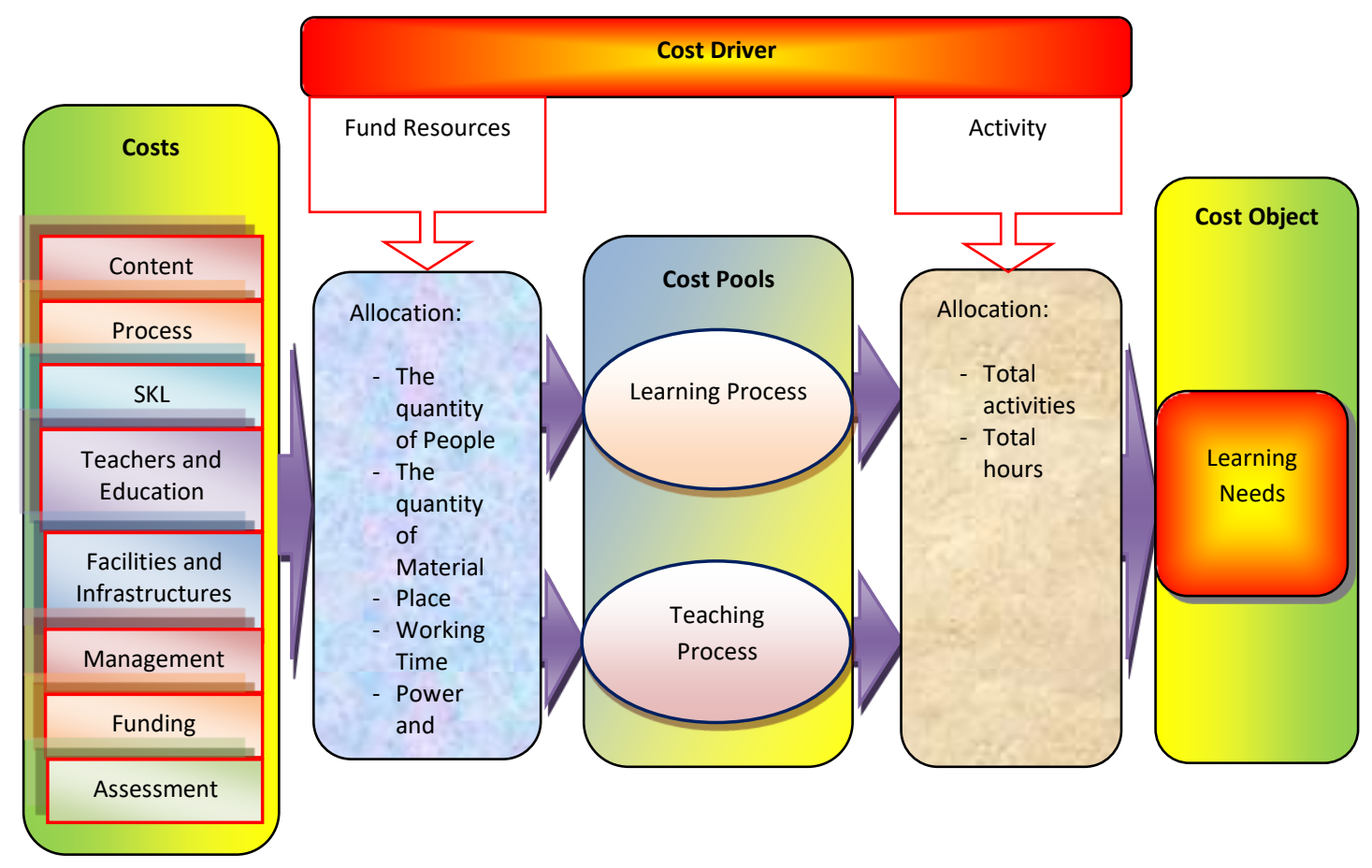

The illustration of Leadership Role in Funding Education in Each Stage of Education in Regional Autonomy Era

In relation to the illustration, several steps must be done in order to determine the methods in calculating the cost:

\section{Identifying the cost of resources and activity}

The process of identification can be done by analyzing the activity to obtain the exact amount of cost resources and elementary school's activity. By analyzing this, the school has to identify several tasks performed by the school such as:

a. What activities that will be done in accordance to the component of education? b. How long does it take to do that kind of activity?

c. What kind of value does it have for the school and students?

2. Imposing the cost of resources towards the cost of activity

The activity triggers the cost of resources that is used in operation. For this reason, school has to choose the cost driver of resource consumption, which encompasses:

a. The quantity of people

b. Material used 
c. Place

d. Working time

e. Power and service

3. Imposing the cost of activity towards the cost's object

This step is the final step where the cost of the activity or the cost pools is imposed to the output according to the exact cost driver of activity consumption. This output is the object of the cost from the activity that had been done in the school; the result of learning process suited for the students' needs.

The main aspect before determining the amount of expenses that must be spent by the school is to set a component that will be the source of the cost. The schools should have the standard reference for the source of the cost in general so that the execution of the schools' activity will be consistent. Therefore, the component that can be used as a source cost can be looked in Government Regulations number 19, 2005, which stated about National Education Standard that has a possibility to be familiar with activities that presses the cost of education and the Government Regulations number 48, 2008 about Educational Funding to investigate the types and group costs. The schools should do these actions since these provisions have become the standard regulation for every institution that runs education nationally.

Furthermore, there are components of cost that can be used as a criterion of resource costs according to Government Regulations number 19, 2005: 1) The standard of contents; 2) The standard of process; 3) The standard competence of graduates; 4) The standard of teachers and educators; 5) The standard of facilities and infrastructures; 6) The standard of management; 7) The standard of funding; 8) The standard assessment of education. [2]

After establishing components that should be focused on in funding education, the schools must determine activities that will be the cost driver in executing learning process. Then, the types of activity that becomes the costs and the result of expenses can be juxtaposed with the aims and goals that will be accomplished by the schools.

However, those can be accomplished if the vision and mission of the school is similar to the vision and mission of regional administration, especially the Department of Education and Culture in a certain region and related schools. The aforementioned and explained illustration was the example of how schools should manage their funding and the expected result that would be accomplished in learning process so that the process could fulfill the needs of students, which is called cost object.

Correspondingly, the policy, which may be considered, is related to:

- Developing awareness, will, and political commitment towards the development of education
- Finding alternative fund resource to subsidize national education

- Improving the efficiency of funds utilization

- Establishing integrated budgeting system.

\section{CONCLUSION}

In the era of regional autonomy, the educational funding is not the responsibility for the central administration only, but it is a shared responsibility between government, regional government, and citizens. The advancement of science and technology and the tight competition between labor markets encourage schools to provide the competitive and high-quality graduates. To do that, the schools have to prepare a large amount of funds so that they can provide the aforementioned criteria of graduates. Educational institution should be more independent, creative, and innovative in exploring and allocating various resources and funds for educational funding.

Unfortunately, there is no fundamental change in educational funding since the establishment of regional autonomy and school autonomy. Moreover, financing at state schools still rely on government's funding while private schools tend to rely on the parental funding. To be more precise, a cost is one of the three most important things in management along with facility and time.

A headmaster as the leader has to focus on learningfocused schools, which encompasses curriculum, learning process, assessment of the result of learning process. Moreover, a headmaster also should plan a strategy to look for funds and fulfill educational funding in the era of regional autonomy.

Educational leaders in general and principals in particular have to be student-oriented, in other words, they have to focus more on students' needs because the primary mission of the school is to focus on teaching and learning. Not to mention thatt school effectiveness also often measured according to the students' achievement. In order to realize the aforementioned condition, it takes no small amount of funding since the role of leadership has to be applied in order to manage and arrange the education's financing. Instructional leadership is not only required to be able to pay attention to the result of students' learning process but should also be able to create a strategy in order to fulfill the necessary amount of funding in learning process.

\section{REFERENCE}

[1] Undang-Undang Nomor 32 Tahun 2004 Tentang Otonomi Daerah

[2] Undang-Undang No. 20 Tahun 2003 Tentang Sistem Pendidikan Nasional

[3] Dadang Suhardan, Riduwan, dan Enas. (2012). Ekonomi dan Pembiayaan Pendidikan. Bandung: Alfabeta

[4] Mohammad Fakry Gaffar, 2000). Pembiayaan Pendidikan: Permasalahan dan Kebijaksanaan Dalam Perspektif Reformasi 
Pendidikan Nasional. Konvensi Nasional Pendidikan Indonesia IV. Jakarta 19-22 September 2000.

[5] ------ (1982). Komunikasi Organisasi Teori dan Proses. IKIP: Bandung.
[6] Daresh, John C. And Playko, Marshal A. (1995). Supervision as a Proactive Process. Waveland press.

[7] Blocher, Chen, Cokins, Lin, (2007). Cost Management (Manajemen Biaya: Penekanan Strategis), Jakarta, Salemba Empat 